\title{
The Dangerous Prevalence of Fiction
}

\author{
By Samuel Storrs Howe
}

Fiction is the act of inventing what is false or unreal. In literature, this false invention is variously called a tale, or a novel, or a romance. In this species of light literature, the subject, the style, and the story are false or fictitious; otherwise history, or the biography, or narrative would naturally be the form of the literary production.

The sin of literary fiction lies in the act of inventing, or publishing, or selling, or reading, or reviewing, whether for pleasure or profit, whatsoever is false in any print or book.

"If book it might be called, which book is none,

Distinguishable in volume, page or line,

Or substance might be called, that shadow seemed."

To detect and expose the sin of fiction as now briefly defined and described, will not be difficult, if regard be had to its evil consequences, on society at large, and especially to its ruinous effects upon the female sex, whose exquisite sensibilities and tender feelings make woman peculiarly susceptible of bad impressions from the romance of light literature. Some of these injurious effects may be properly stated here, to prove the sinfulness of fiction.

1. Fiction destroys the love of truth. This it does by introducing into the mind a passion for the notoriously false and extravagant details of fiction, in whatsoever words of romance these falsities and extravagances may be rendered attractive to a reading public. Besides, it is a natural law of the human mind, that a willing familiarity (such as readers must have who are fond of romance), with error, always blunts the feelings of regard to the exact truth. Hence, the renowned British statesman, Edmund Burke, of a former age, said, "he would not let his servant tell a lie in his hearing every day, lest he should, at length, begin to believe it himself." And, on the same principle of moral assimilation, who, though possessed of the strongest intellect, and safely and familiarly indulge and amuse the mind with all the fictions of light literature, even to satisfy, without contracting some- 
thing of their bewitching falsity? Will not the giddy girl most assuredly catch the lying spirit of the pretty tale which she reads? Will not the young woman imbibe the delusive sentiment of the novel of her choice? Will not the wife or the mother contract the bewitching passion of the wild romance of her liking? In short is there not great danger that the passion for fiction will gradually destroy the love of honest truth, till history, biography, narrative and ordinary matters of fact have lost their relish? And what is female character without truthfulness? And shall victorious love of truth, as both the shield and the ornament of woman, be sacrificed to the vain passion for fiction? Who would thus endanger the honest love of truth in woman, by means of the false and fictitious literature, already too prevalent both in the city and in the country?

2. Fiction, also, causes dissipation of the mind. This is a natural effect of fairy tales, dreamy novels, and visionary romances, the inventors of which labor only to give to

\section{"Airy nothing}

A local habitation and a name."

Neither the writer nor the reader of such false imaginings, can have any great occasion for intellectual exertion or mental discipline, but on the contrary, by sort of busy, moody idleness, and by the overworking of an erring fancy, must gradually sink down into a sort of debauch or dissipation of mind, very well described by the poet Pollock:

"A novel was a book

Three volumed, and once read; and oft crammed full

Oh pois'nous error, black'ning every page;

And oftener still of trilling, second hand

Remark, and old, diseased putrid thought

And miserable incident, at war

With nature, with itself and truth at war;

Yet charming still the greedy reader on,

Till done-he tried to recollect his thoughts,

And nothing found but dreamy emptiness."

3. Ficton, moreover, occasions the corruption of manners. Nor, are the manners of the female sex to be overlooked since "manners are minor morals," as Dr. Paley has well said. And whatever degenerates or vulgarizes good manners, is certainly to be avoided by the politer sex. To say nothing, however, of the levities and frivolities which are grouped to- 
gether in most of the flashy and trashy fictions of our times, recent novelists do not inculcate the government of the passions and of the imagination, nor the old household words and ways of life, as did Johnson in a former age, when in his romances he dissuaded from the desire of sudden wealth, which says: "Let the golden stream be quick and violent," and when he discoursed on "the dangerous prevalence of the imagination." Late novelists have little or none of the practical wisdom and easy politeness of Goldsmith, who in his masterly style of description, forgot not the "good night" and the "good morning" of a happy home, in his Vicar of Wakefield, adding also the practical maxim, as he has always found it to be true in good manners, "that where the forms of politeness are neglected, the feelings subside pretty soon." Indeed, the most popular writers of fiction, now-adays, seems to aspire to represent love (and that is the principal passion of their works of fancy):

"In the bought smile

Of harlots, loveless, unendeared.

In court amours,

Mixed dance, or wanton mask, or midnight ball,

Or serenade, which the proud lover sings

To his proud fair, best quitted with disdain."

Can there be any surprise or wonder, therefore, that often not only the opera or the theatre, but also the harlot's house should be the last resort and result of the tempting, polluted manners - "the minor morals" - of romance? And, even where innocent and virtuous manners are maintained, notwithstanding the corrupting allurements of vicious fiction, yet how sad are the traces of the habits and manners of romance, still left on the mind, now so utterly unfitted for the sober realities of life. Said an intelligent woman in the wilderness of Fiction to a passing colporteur, as she recalled to memory fictions she had read in her youth, without stint or restraint, - "Novels are not the books for the woods. .." the tears flowing down her face, as she spoke from her own bitter experience. Indeed, the unnatural and unreal manners of heroes and heroines of romance, would be as unlikely, if imitated by the readers of fiction, to produce substantial happiness on earth, as the paradise of motherhood would be, to promote immortal bliss in heaven! 
4. Fiction induces, likewise, the depravation of morals. Many modern and recent romances are decidedly demoralizing in their character. If their authors had made the depravation of female morals their object, to be kept constantly in view, they could not seemingly have catered more effectually for the moral corruption of woman, than they have done. Rousseau, for example, in the preface to his novel, entitled "Eloize, or A Necessary Life in a Corrupt State of Society," - says expressly:

"The style of my work will offend people of taste, the matter will alarm the decent, and scandalize women of virtue, but as to girls reading it! She who shall dare to read a single page of it is lost forever!"

Oh! what corruption of the otherwise chaste minds of daughters, sisters, wives - what depravation of woman's morals, even to her fall, has sprung from the polluting fictions of lascivious romance!

"When lovely woman stoops to folly,

And finds too late that men betray,

What art can sooth her melancholy?

What tears can wash her guilt away?"

And still the novelist, the publisher, the bookseller, the reviewer recommending the vicious thing of fiction, as well as the seducer, are panderers to woman's guilt, and partakers of woman's sin and ignominy.

Yet the indulgent advocate of fiction may say, perhaps, as in the language of an English writer, - "Oh! but there is a moral in these things." No doubt of it. There is a moral in all sin and wickedness. There is a moral everywhere, and the variest bungler cannot fail to see it. But is that the reason why our sons and daughters must be corrupted by what is notoriously the nearest thing to contact with absolute vicenamely, vivid and graphic discriptions of it by writers of undenied ability. Did life in London, or the exploits of Thom, Jerry and Logic, make the youth of the metropolis mere staid, or inspire them with a horror of dissipation? Did the memories of Cazanora reclaim a rake-the autobiography of David Haggart convert an aspiring pickpocket-or the daring feats of Jack Sheppard arrest one candidate for the gallows?"

5. Fiction deadens the benevolent and religious susceptibit- 
ities. How can any person enervated by dreams and tears over unreal scenes of suffering as depicted in the darkest shades of romance, have any heart left to weep over the real woes of mortals, in lanes and hovels, that well might bathe humanity in tears. Besides, the excitement of the benevolent feelings, for mere amusement, or for no real cause as is the case with all novelists or novel-readers, by the very force of a natural law of the mind, wastes and wears out the finer sensibilities, till real distress has no power to attract relief from the interposition of romantic minds. And, as for the religious susceptibilities of the heart to which the Bible, the Sabbath, sanctuary of worship, and the closet of devotion appeal,-these are naturally repressed and deadened, where fictions are made a person's pastime. How can a person be alive to the beauty of Divine truth, when shrouded in the drapery of romance! How can an individual well pray over a novel! How can communion with saints, and angels, and Christ be cultivated when the mind is mostly conversant with the distorted, or debauched characters of romance!

The mind is its own place, and in itself

Can make a heaven of hell, a hell of heaven.

And, in this view, the mind by its fictitious and romantic associations would make "a hell" everywhere, regardless of God and man.

Besides, many novel-writers would seem to take delight in traducing "religion pure and undefiled," by resorting to miserable caricatures of piety and Christianity. Even Sir Walter Scott, that prince of novelists, and who has much to answer for by misleading many inferior imitators, often introduces both characters and sentiment in his fictitious writing, wholly at variance with the Christian religion. While other writers, far less cautious than Scott, seem to have felt and written like Voltaire,-saying, "I must and will be read; and give me six witicisms a day, and I will make head against a religion which it took Christ and his twelve apostles to establish in the world." Thus, too often, are fiction and infidelity closely allied in the minds of both writers and readers of romance.

6. Fiction causes, also, insanity. The reason and all the mental faculties sometimes lose their balance by the bewil- 
dering influence of fictitious literature over the imagination. More than one lunatic asylum, if the register of the causes of madness are duly kept, will contain inmates brought there by the influence of tales, and novels and romance - that truthless literature of this age. And the wretched maniac bereft of reason and natural affection, is thus the sad realization of the terrific sentence-"She is mad." And outside of the insane hospital, more than one female of whom it must be acknowledged, as one father actually confessed that "excessive reading" of fiction had given "his daughter fits of insanity," while several well-thumbed volumns of "Eugene Sue," or of some other similar authors, were on the shelves.

7. Fiction leads likewise to suicide. The cases of self-murder from the mischievous effects of wild and extravagant romance are a most startling comment upon the guilt of writing, publishing, selling, lending and reading fictitious works, which lure but to destroy. Take the following instance from the N.Y. weekly Journal of Commerce, for December 10, 1851:

"Melancholy Suicide.-Elsey A. Huxford, aged 19, a pupil of Miss Wells' boarding school at Pittsfield, (Mass.), committed suicide, on Wednesday night last, by drowning herself. Her body was found in the river near Tayior's Bridge, about a mile south of the village, on Sunday morning. She left a note addressed to one of the teachers of the school, in which she intimates her intention to commit suicide, and gives as the cause-want of friends, troubles and trials in life, NOVEL READING, etc." Such then confessedly is the very climax of deadly consequenced flowing from writing, printing, selling and reading works of fiction. Self-murder, and novel-reading as the cause! Who wrote the novel that did the deed of death by drowning? Who printed and published it? Who sold or loaned it to Elsey A. Huxford?

With what awful consequences, then, does death invest the subject of novels and novel-reading-nay, all fictitious publications, in the daily, weekly, monthly, quarterly, annual and continual issues of the secular press, multiplied like the vermin of Egypt, in the days of her ancient plagues, and crawling into all the houses of high and the low, read as are these multiplied fictions by the great and the small, in the 
city and in the country! According to an average made from the actual issues for a single month of 1843, New York City, of all the periodical printing, exclusive of cheap pamphlets, "nearly twice as much periodical printing in New York was devoted to fictitious and injurious matter as to commerce, and nearly three times as much as to political and religious intelligence." And, as is the chief city, so is the country, flooded with the putrid waters of corrupt and corrupting literature, carrying death, temporal and eternal to its devotees, by night and by day.

With what awful moment, therefore, be it repeated, does this putrid flood of fiction invest the life and the death of erring mortals! It was night, with all nature thickly clad in sable darkness, as that ill-fated Steamboat Swallow struck on a rocky islet in the North river, and suddenly engulfed in a watery grave, two young women among other passengers who lost their lives. When their lifeless bodies were at length discovered, one young woman held in her clenched hand, with the firm grasp of death, a novel! called the "Grumbler!" The other still grasped the memoir of the pious Mary Lundie Duncan-a serious narrative of truth! Now, ye gay and thoughtless daughters, wives, mothers, grasping which, would you choose to die-a novel of fiction or a narrative of truth? Which do you prefer as your favorite volume? But tell me not what works, whether of fact or fiction, you would wish to grasp in the last struggle of death, as the drowning person catches at straws: but tell me what sort of publication you have in your hands, your parlors, your chambers, your studies, while you live, and I will predict how, without the grace of a neglected God and the truth of a rejected Bible intervene, you will most assuredly die; since death must soon come, "which comes to all." And after death is the judgment and the eternal state of all the dead. Oh! how will all authors, and publishers, and sellers, and readers and reviewers of fictitious and injurious writing while on earth then awake in the fell agonies of everlasting despair, with crimination and recrimination for having been the cause of the ruin of one another, soul and body, in hell! No wonder! that Hoffman the novelist when lying paralyzed in every limb and muscle, exclaimed, - "life-LIFE-LIFE-only, and on any 
condition!" Surely, novels are not the books to die by, if they are fraught with such ruinous consequences, to both soul and body. But who shall describe the spirit lost in eternal perdition?-

"Me miserable! which way shall I fly

Infinite wrath, and infinite despair?

Which way is hell? myself am hell;

And, in the lowest deep, a lower deep,

Still threatening to devour me opens wide,

To which the hell I suffer seems a heaven."

Such, indeed are some of the dreadful consequences of fictious publications, as faintly depicted in this short tract. Who now is willing to be accessory to this grievous and heinous sin of fiction, as destroying the love of honest truth, as causing dissipation of the mind, corruption of manners, depravation of morals, deadening the benevolent and religious sensibilities, leading to self-murder and the eternal loss of both soul and body in hell! Who would be guilty of writing, printing, sellling, reading or reviewing what tends to all this misery interminable for profit or for pleasure, for pay or for pastime? Yet how many minds and hands are thus engaged? Will it ever be known? Yes, the judgment day will reveal the guilty, when "God shall bring every work into judgment, with every secret thing, whether it be good, or whether it be evil," (Prov. 12:14). Who then will be guiltless, and not speechless rather, than has been thus engaged in either inventing or perpetuating fictions?

But it may be objected to these views, that they are extreme,-that even good people write fictions, and better folks even read them-such as old John Bunyan and his admirers. Since Pilgrim's Progress is only an allegory-not a narrative of matters of fact; and since even the Parables of Christ and the prophets, are only comparisons, and not real occurrences. Nay, that even some novels are truer to nature than many other writings of higher pretensions to veracity. In reply, it is readily admitted, that it is hard to separate the precious from the vile, or to distinguish that which inculcates only truth, and virtue, and piety, as do scriptural Parables, and as Bunyan's Pilgrim's Progress does under allegorical representations, from that which instils more or less falsity, immorality and irreligion. Yet, discriminate, all must do, or 
else suffer the bitter consequences. In general, any book of work of any writer, which discloses the least deviation from truth, of the least wanton or wicked allusion, should be shunned, as one would avoid poison. And, although

The flowers of eloquence profusely poured

O'er spotted vice, fill half the lettered world.

Yet, books enough remain, for a short hasty life. One cannot read every thing. Nor is it necessary to eat all "the apples of Sodom" to learn that they are bitter. Nor are people born to merely chase butterflies and hunt for buttercups, like little children; for death is too near the door.

EDITOR's Note: The above was written for the ANNALs in 1884. Have times changed?

\section{About the Picture on the Cover ...}

The picture on the cover is a sketch of the most recently acquired statue on the state capitol grounds. The statue, of Lincoln and his son, Tad, was given to the state by the Friends of Lincoln last November 19.

This fall marks the 100th anniversary of Lincoln's Emancipation Proclamation, the first being delivered September 22, 1862 with the permanent emancipation act following it January 1, 1863. Lincoln gave his Gettysburg Address on November 19, 1863.

"The name of Lincoln had a special meaning to the people of Iowa because it was he who signed the Homestead Act, granting one hundred sixty acres of public land to anyone agreeing to cultivate it for five years, which cleared the way for the settling of Iowa. Another bill that Lincoln signed the Land-Grant College Act, established Iowa State University at Ames. His name has been given to the highway crossing our state which binds our nation together in transportation even as Lincoln himself bound our country together politically." *

*Douglas Nelson

Barbara Gribben

South Hamilton Community Schools 
Copyright of Annals of Iowa is the property of State of Iowa, by \& through the State Historical Society of Iowa and its content may not be copied or emailed to multiple sites or posted to a listserv without the copyright holder's express written permission. However, users may print, download, or email articles for individual use. 